\title{
PENGARUH BELANJA DAERAH SERTA TENAGA KERJA TERHADAP PRODUK DOMESTIK REGIONAL BRUTO PROVINSI KALIMANTAN UTARA
}

\author{
Machmud Al Amrie ${ }^{1}$, Adi Aspian Nur ${ }^{2}$,Amelia Ramadhani ${ }^{3}$ \\ 1 Fakultas Ekonomi, Universitas Kaltara. Jalan Sengkawit, Tanjung Selor, Bulungan, Kalimantan \\ Utara 73212, Indonesia. \\ E-mail : machmudalamrie@gmail.com \\ 2 Fakultas Ekonomi, Universitas Kaltara. Jalan Sengkawit, Tanjung Selor, Bulungan, Kalimantan \\ Utara 73212, Indonesia. \\ E-mail : adiaspiannur22@gmail.com , Telp +6281351876400 \\ 3 Jurusan Ekonomi Pembangunan, Fakultas Ekonomi, Universitas Kaltara. Jalan Sengkawit, \\ Tanjung Selor, Bulungan, Kalimantan Utara 73212, Indonesia.
}

\begin{abstract}
Abstrak
Tujuan penelitian adalah untuk menganalisis pengaruh Belanja Daerah terhadap Produk Domestik Regional Bruto Provinsi Kalimantan Utara. Serta menganalisis pengaruh Tenaga Kerja terhadap Produk Domestik Regional Bruto Provinsi Kalimantan Utara.

Hasil penelitian diperoleh bahwa belanja daerah secara langsung berpengaruh signifikan terhadap Produk Domestik Regional Bruto Provinsi Kalimantan Utara. Selanjutnya variabel tenaga kerja secara langsung berpengaruh signifikan terhadap Produk Domestik Regional Bruto Provinsi Kalimantan Utara.
\end{abstract}

Kata Kunci : Belanja Daerah, PDRB Kalimantan Utara

\section{Pendahuluan}

Tujuan pembangunan pemerintah Provinsi Kalimantan utara perlu meningkatkan sumber penerimaan daerah sendiri yang pada akhirnya berpengaruh terhadap tingkat perkembangan ekonomi daerah yang dilihat dari perkembangan nilai tambah atau Produk Domestik Reginal Bruto (PDRB), melalui sumber penerimaan daerah yang ditetapkan dalam Anggaran Pendapatan dan Belanja Daerah (APBD) (1)

Anggaran Pendapatan dan Belanja Daerah (APBD) pada hakikatnya merupakan wujud pengelolaan keuangan daerah yang setiap tahunnya ditetapkan dengan peraturan daerah, tidak terkecuali wilayah Kalimantan utara. Struktur anggaran pendapatan dan Belanja Daerah Kalimantan Utara terdiri atas:

1. Anggaran Pendapatan Daerah

2. Anggaran Belanja Daerah

3. Pembiayaan 
Pendapatan Asli Daerah (PAD) yaitu :

1. Hasil pajak Daerah.

2. Hasil retribusi Daerah

3. Hasil perusahaan milik Daerah, dan hasil pengelolaan kekayaan Daerah yang dipisahkan.

4. Lain-lain Pendapatan Asli Daerah yang sah.

5. Dana Perimbangan, yaitu : Bagian Daerah dari penerimaan Pajak Bumi dan Bangunan (PBB), Bea Perolehan Hak atas Tanah dan Bangunan, dan penerimaan dari sumber daya alam.

6. Dana Alokasi Umum (DAU).

7. Dana Alokasi Khusus (DAK).

8. Pinjaman Daerah.

9. Lain-lain Pendapatan Daerah yang sah (1)

Diharapkan pemerintah Kalimantan utara dapat mengelola sumber-sumber penerimaan tersebut dengan baik dan diharapkan nantinya dapat dipergunakan untuk kegiatan-kegiatan ekonomi yang dapat meningkatkan kesejahteraan masyarakat (1)

Upaya meningkatkan sumber pendapatan yang nantinya berpengaruh dalam meningkatkan perkembangan ekonomi di daerah yakni Produk Domestik Regional Bruto (PDRB), pemerintah dapat menitikberatkan pada sumber Pendapatan Asli Daerah (PAD), Investasi serta Sumber Daya Manusia (SDM) atau Tenaga Kerja (1)

Belanja Daerah provinsi Kalimantan utara pada tahun 2009 sebesar Rp 6.309.258.870,- dan pada tahun 2010 jumlah Belanja Daerah provinsi Kalimantan utara menurun sebesar Rp 5.918.568.270,kemudian meningkat pada tahun 2011 sebesar Rp 8.142.835.450,- (2)

Penduduk yang bekerja di Kalimantan utara pada tahun 2009 sebesar 1.460 .996 jiwa. Pada tahun 2010 penduduk yang bekerja 1.481 .898 jiwa. Pada tahun 2011 penduduk yang bekerja sebesar 1.591 .003 jiwa (2)

Produk Domestik Regional Bruto (PDRB) atas harga konstan Kalimantan utara pada tahun 2009 sebesar Rp 105.564.938.000.000,-. Pada tahun 2010 nilai Produk Domestik Regional Bruto (PDRB) Kalimantan utara sebesar Rp 110.953.452.000.000,-. Pada tahun 2011 Produk Domestik Regional Bruto (PDRB) Kalimantan utara sebesar Rp 115.475.684.000.000,- (2)

Dari hasil uraian atas maka permasalahan yang yang terjadi adalah dengan meningkatnya pertumbuhan ekonomi baik di bidang swasta asing dan juga penanaman dari dalam negeri serta di dukung juga oleh membaiknya sektor-sektor perekonomian di kalimantan utara akan tetapi belum diikuti oleh peningkatan kesempatan kerja yang signifikan atau keseluruhan, serta belum mampu menyerap tenaga kerja yang tersedia menyeluruh sehingga masih ada tenaga kerja yang belum diberdayakan dalam bentuk pengangguran. Belanja Daerah merupakan pengeluaran pemerintah atau pengeluaran pembangunan yang bertujuan untuk menciptakan kegiatan-kegiatan ekonomi yang mana akan mendukung peningkatan PAD (2)

\section{Metode Penelitian}

\section{Hipotesis}

Hipotesis yang diajukan adalah (1) Belanja Daerah secara langsung berpengaruh signifikan terhadap Produk Domestik Regional Bruto Provinsi Kalimantan Timur; (2) Tenaga Kerja secara langsung berpengaruh signifikan terhadap Produk Domestik Regional Bruto Provinsi Kalimantan Timur.

\section{Rancangan Penelitian}

Rancangan penelitian ini terdiri dari elemen-elemen yang merujuk pada bentuk penelitian non contrived. Di sini peneliti hanya mengumpulkan data tanpa memberikan perlakuan apapun terhadap data tersebut dengan maksud dan tujuan pencarian solusi dari masalah yang telah dirumuskan, sehingga beberapa hipotesis yang telah dikonstruk dapat diuji secara empirik.

Berdasarkan maksud dan tujuan tersebut, penelitian ini menggunakan metode penelitian survei dengan pendekatan penelitian kuantitatif. Jenis penelitian survei ini memfokuskan pada pengungkapan 
hubungan kausal antar variabel secara langsung dan tidak langsung, yaitu penelitian yang diarahkan untuk menyelidiki hubungan sebab berdasarkan pengamatan terhadap akibat yang terjadi.

\section{Rincian Data Yang di Perlukan}

Data merupakan komponen yang penting dalam penelitian ini, karena akan digunakan untuk melakukan perhitungan. Adapun rincian data yang diperlukan adalah sebagai berikut :

1. Gambaran umum wilayah Kalimantan utara.

2. Data Produk Domestik Regional Bruto atas harga berlaku dari tahun 2010 sampai dengan tahun 2017 untuk wilayah Kalimantan Utara.

3. Data Tenaga kerja yang terserap dari tahun 2010 sampai dengan tahun 2017 di Kalimantan utara.

4. Data Belanja pembangunan dari tahun 2010 sampai dengan tahun 2017 di Kalimantan utara.

5. Data lainnya yang menunjang penelitian ini.

\section{Teknik Pengumpulan Data}

Teknik pengumpulan data dalam penelitian ini adalah Studi kepustakaan, dilakukan dengan tujuan untuk mendapatkan atau memperoleh teori-teori yang mendukung penelitian dan diambil dari literatur maupun buku-buku, artikel ilmiah serta penelitian sebelumnya.

\section{Analisis Data}

Analisis data atau perhitungan statistik dalam penelitian ini didasarkan atas kerangka konsep, rumusan masalah serta hipotesis. Adapun perhitungan statistik yang dipergunakan adalah :

$$
Y_{1 t}=P_{1} x_{1 t}+P_{2} x_{2 t}+e_{t}
$$

Dimana dalam penelitian :

$\mathrm{Y}_{1 \mathrm{t}} \quad=$ Produk Domestik Regional Bruto

$\mathrm{P}_{1} \mathrm{X}_{1 \mathrm{t}} \quad=$ Belanja Daerah

$P_{2} x_{2 t} \quad=$ Tenaga kerja

$\mathrm{e}_{\mathrm{t}} \quad=$ Error term atau nilai residual

\section{Hasil dan Pembahasan}

\section{Belanja Daerah}

Belanja pembangunan atau belanja daerah merupakan pengeluaran pemerintah yang dipergunakan untuk kegiatan pembangunan. Diharapkan dengan adanya pengeluaran pemerintah untuk sektor pembangunan dapat meningkatkan nilai PDRB. Tentunya agar pengeluaran pemerintah dapat efektif dan efisien perlu adanya suntikan dana yaitu investasi. Investasi bisa diperoleh dari pihak negeri ataupun swasta atau yang lebih dikenal dengan PMDN dan PMA. Tentunya pihak investor berharap dengan menanamkan investasi pada suatu daerah tingkat return of investment cepat terjadi. Data belanja daerah provinsi Kalimantan utara adalah sebagai berikut :

Table 1 Belanja Daerah Provinsi Kalimantan Utara

\begin{tabular}{cr}
\hline Tahun & Belanja Daerah Provinsi Kalimantan utara ( Ribu Rupiah) \\
\hline $\mathbf{2 0 1 0}$ & 2.629 .006 .470 \\
$\mathbf{2 0 1 1}$ & 2.093 .467 .730 \\
$\mathbf{2 0 1 2}$ & 3.768 .786 .320 \\
$\mathbf{2 0 1 3}$ & 4.689 .695 .908 \\
$\mathbf{2 0 1 4}$ & 6.356 .384 .491 \\
$\mathbf{2 0 1 5}$ & 6.309 .258 .870 \\
$\mathbf{2 0 1 6}$ & 5.918 .568 .270 \\
$\mathbf{2 0 1 7}$ & 8.142 .835 .450 \\
\hline
\end{tabular}

Sumber : KALTARA DALAM ANGKA 2018 


\section{TENAGA KERJA}

Pasar tenaga kerja sebagai suatu pasar yang mempertemukan suply dan demand tenaga kerja. Sebagai penjual tenaga kerja dalam pasar ini adalah para pencari kerja (Pemilik Tenaga Kerja), sedangkan sebagai pembelinya adalah orang-orang/lembaga yang memerlukan tenaga kerja. Pasar tenaga kerja diselenggarakan dengan maksud untuk mengkoordinasi pertemuan antara para pencari kerja dan orangorang atau lembaga-lembaga yang membutuhkan tenaga kerja.

Dalam rangka untuk memenuhi kebutuhan tenaga kerja dari perusahaan, maka pasar tenaga kerja dapat memberikan jalan keluar bagi perusahaan untuk memenuhinya. Dengan demikian tidak terkesan hanya pencari kerja yang mendapat keuntungan dari adanya pasar ini. Untuk menciptakan kondisi yang sinergi antara kedua belah pihak, yaitu antara penjual dan pemberi tenaga kerja maka diperlukan kerjasama yang baik antara semua pihak yang terkait, yaitu penjual tenaga kerja, pembeli tenaga kerja, dan pemerintah. Data perkembangan tenaga kerja di Kalimantan utara adalah sebagai berikut :

Table 2 Perkembangan Tenaga Kerja di Kalimantan Utara Tahun 2004-2013

\begin{tabular}{ccc}
\hline TAHUN & $\begin{array}{c}\text { ANGKATAN KERJA } \\
\text { (Jiwa) }\end{array}$ & $\begin{array}{c}\text { PENDUDUK BEKERJA } \\
\text { (Jiwa) }\end{array}$ \\
\hline $\mathbf{2 0 1 0}$ & 1.162 .209 & 1.041 .494 \\
$\mathbf{2 0 1 1}$ & 1.171 .891 & 1.078 .094 \\
$\mathbf{2 0 1 2}$ & 1.324 .878 & 1.146 .881 \\
$\mathbf{2 0 1 3}$ & 1.241 .421 & 1.091 .625 \\
$\mathbf{2 0 1 4}$ & 1.416 .963 & 1.259 .587 \\
$\mathbf{2 0 1 5}$ & 1.460 .996 & 1.302 .772 \\
$\mathbf{2 0 1 6}$ & 1.648 .455 & 1.481 .898 \\
$\mathbf{2 0 1 7}$ & 1.764 .696 & 1.591 .003 \\
\hline
\end{tabular}

Sumber : KALTARA DALAM ANGKA 2018

\section{Produk Domestik Regional Bruto}

Produk Domestik Regional Bruto (PDRB) merupakan nilai kegiatan perekonomian suatu daerah berupa barang dan jasa yang dihasilkan dalam setahun atau periode tertentu. Semakin besar kegiatan menghasilkan barang dan jasa yang dihasilkan maka akan semakin besar pula nilai PDRB. Data Produk Domestik Regional Bruto (PDRB) Provinsi Kalimantan Utara adalah sebagai berikut :

Table 3 Pertumbuhan Nilai Produk Domestik Regional Bruto Provinsi Kalimantan utara atas Harga konstan 2000 Tahun 2004-2013

\begin{tabular}{ccc}
\hline Tahun & PDRB (Juta Rupiah) & Laju Pertumbuhan $(\%)$ \\
\hline $\mathbf{2 0 1 0}$ & 91.050 .429 & 1,75 \\
$\mathbf{2 0 1 1}$ & 93.938 .002 & 3,17 \\
$\mathbf{2 0 1 2}$ & 96.612 .842 & 2,85 \\
$\mathbf{2 0 1 3}$ & 98.386 .382 & 1,84 \\
$\mathbf{2 0 1 4}$ & 103.206 .871 & 4,90 \\
$\mathbf{2 0 1 5}$ & 105.564 .938 & 2,28 \\
$\mathbf{2 0 1 6}$ & 110.953 .452 & 5,10 \\
$\mathbf{2 0 1 7}$ & 115.475 .684 & 4,08 \\
\hline
\end{tabular}

Sumber : KALTARA DALAM ANGKA 2018 
Untuk dapat menganalisis pengaruh Belanja Daerah dan Investasi Serta Tenaga Kerja Terhadap Produk Domestik Regional Bruto Serta Pendapatan Asli Daerah di Provinsi Kalimantan Utara, maka terlebih dahulu data-data yang sudah diperoleh pada bab sebelumnya ditabulasikan,Data penelitian yang akan dinput ke dalam proses perhitungan adalah sebagai berikut :

Table 4 Belanja Daerah, Total Investasi, Penduduk Bekerja, PDRB, PAD

\begin{tabular}{cccccc}
\hline Tahun & $\begin{array}{c}\text { BELANJA } \\
\text { DAERAH } \\
(\mathbf{X 1 )}\end{array}$ & $\begin{array}{c}\text { TOTAL (PMA + } \\
\text { PMDN) } \\
(\mathbf{X 2})\end{array}$ & $\begin{array}{c}\text { PENDUDUK } \\
\text { BEKERJA } \\
(\mathbf{X 3 )}\end{array}$ & $\begin{array}{c}\text { PDRB } \\
(\mathbf{Y 1})\end{array}$ & $\begin{array}{c}\text { PAD } \\
(\text { Y2) }\end{array}$ \\
\hline $\mathbf{2 0 0 4}$ & 2.629 .006 .470 & 5.408 .039 .420 .000 & 1.041 .494 & 91.050 .429 & 70.563 .121 .000 \\
$\mathbf{2 0 0 5}$ & 2.093 .467 .730 & 5.156 .352 .539 .000 & 1.078 .094 & 93.938 .002 & 89.751 .582 .000 \\
$\mathbf{2 0 0 6}$ & 3.768 .786 .320 & 3.576 .965 .688 .000 & 1.146 .881 & 96.612 .842 & 119.699 .551 .000 \\
$\mathbf{2 0 0 7}$ & 4.689 .695 .908 & 7.339 .379 .562 .000 & 1.091 .625 & 98.386 .382 & 152.485 .623 .000 \\
$\mathbf{2 0 0 8}$ & 6.356 .384 .491 & 453.834 .812 .000 & 1.259 .587 & 103.206 .871 & 207.029 .261 .000 \\
$\mathbf{2 0 0 9}$ & 6.309 .258 .870 & 3.826 .266 .760 .000 & 1.302 .772 & 105.564 .938 & 220.830 .913 .000 \\
$\mathbf{2 0 1 0}$ & 5.918 .568 .270 & 16.878 .552 .054 .000 & 1.481 .898 & 110.953 .452 & 271.129 .956 .000 \\
$\mathbf{2 0 1 1}$ & 8.142 .835 .450 & 28.328 .877 .680 .000 & 1.591 .003 & 115.475 .684 & 450.323 .882 .000 \\
$\mathbf{2 0 1 2}$ & 11.339 .765 .190 & 29.487 .926 .300 .000 & 1.619 .118 & 120.067 .296 & 540.949 .939 .000 \\
\hline $\mathbf{2 0 1 3}$ & 14.559 .749 .920 & 32.024 .549 .626 .000 & 1.624 .272 & 121.990 .486 & 588.614 .911 .000 \\
\hline
\end{tabular}

\section{Analisis}

Model persamaanbertujuan menganalisis pengaruh Belanja Daerah, Tenaga Kerja, terhadap Produk Domestik Regional Bruto (PDRB) Hasil perhitungan adalah sebagai berikut :

\section{Table 5 Hasil Persamaan I}

\section{Coefficients $^{\mathrm{a}}$}

\begin{tabular}{|c|c|c|c|c|c|c|}
\hline \multirow{2}{*}{\multicolumn{2}{|c|}{ Model }} & \multicolumn{2}{|c|}{$\begin{array}{c}\text { Unstandardized } \\
\text { Coefficients }\end{array}$} & \multirow{2}{*}{$\begin{array}{c}\begin{array}{c}\text { Standardized } \\
\text { Coefficients }\end{array} \\
\text { Beta }\end{array}$} & \multirow[t]{2}{*}{$\mathrm{t}$} & \multirow[t]{2}{*}{ Sig. } \\
\hline & & $\mathrm{B}$ & Std. Error & & & \\
\hline \multirow{3}{*}{1} & (Constant) & $5.73 E+13$ & $4.13 \mathrm{E}+12$ & \multirow[b]{2}{*}{0.297} & \multirow{2}{*}{$\begin{array}{r}13.891 \\
3.723\end{array}$} & \multirow[b]{2}{*}{0.01} \\
\hline & $\begin{array}{l}\text { Belanja } \\
\text { Daerah }\end{array}$ & 839.104 & 225.389 & & & \\
\hline & $\begin{array}{l}\text { Penduduk } \\
\text { Bekerja }\end{array}$ & $3.20 \mathrm{E}+07$ & 4107823.9 & 0.687 & 7.783 & 0 \\
\hline
\end{tabular}

a. Dependent Variable: PDRB

Tabel 5 menghasilkan persamaan adalah sebagai berikut :

$\begin{aligned} \boldsymbol{Y}_{1 t} & =\boldsymbol{P}_{1} \boldsymbol{x}_{1 t}+\boldsymbol{P}_{2} \boldsymbol{x}_{2 t}+\boldsymbol{P}_{3} \boldsymbol{x}_{3 t}+\boldsymbol{e}_{t} \\ & =0,297 \mathbf{X}_{1}+0,687 \mathbf{X}_{3}+\mathbf{e}_{\mathrm{t}}\end{aligned}$

Di mana :

Y adalah Produk Domestik Regional Bruto

$\mathrm{X}_{1}$ adalah Belanja Daerah berpengaruh positif terhadap $\mathrm{Y}_{1}$ Produk Domestik Regional Bruto dengan nilai koefisien sebesar 0.297.

$\mathrm{X}_{2}$ adalah Tenaga Kerja berpengaruh positif terhadap $\mathrm{Y}_{1}$ Produk Domestik Regional Bruto dengan nilai koefisien sebesar 0.687. 


\section{Koefisien Korelasi (R) dan Koefisien Determinasi $\left(\mathbf{R}^{2}\right)$}

Nilai koefisien korelasi $(R)$ dan koefisien determinasi $\left(R^{2}\right)$ untuk persamaan adalah sebagai berikut :

Table 6 Uji Goodness of Fit Model Summary

\begin{tabular}{|l|r|r|r|r|}
\hline Model & \multicolumn{1}{|c|}{$\mathrm{R}$} & R Square & \multicolumn{1}{c|}{$\begin{array}{c}\text { Adjusted R } \\
\text { Square }\end{array}$} & $\begin{array}{c}\text { Std. Error of } \\
\text { the Estimate }\end{array}$ \\
\hline 1 & $.996^{\mathrm{a}}$ & .992 & .987 & $1.240 \mathrm{E} 12$ \\
\hline
\end{tabular}

a. Predictors: (Constant), Penduduk Bekerja, Total (PMA + PMDN), Belanja Daerah

Koefisien korelasi sebesar $\mathrm{R}=0.996$ angka ini menunjukkan tingkat hubungan atau korelasi sangat kuat dari variabel belanja daerah $\left(\mathrm{X}_{1}\right)$, tenaga kerja $\left(\mathrm{X}_{2}\right)$ terhadap PDRB $\left(\mathrm{Y}_{1}\right)$.

Koefisien determinasi $\left(\mathrm{R}^{2}\right)$ dalam penelitian ini yang dipergunakan adalah adjusted $R$ square yaitu 0,987 . Artinya variabel independen untuk model persamaan I memberikan pengaruh terhadap PDRB sebesar $98,7 \%$ dan sisanya $1,2 \%$ dipengaruhi oleh faktor lain.

\section{Uji F}

Pengujian hipotesis uji $\mathrm{F}$ atau Fisher Test pada tingkat kepercayaan $95 \%$ dan tingkat kesalahan sebesar $\alpha=0,05$ dapat dilihat pada tabel berikut :

\section{Table 7 Hasil Perhitungan Uji F} ANOVA ${ }^{b}$

\begin{tabular}{|ll|r|r|r|c|c|}
\hline Model & & Sum of Squares & df & Mean Square & F & \multicolumn{1}{c|}{ Sig. } \\
\hline 1 & Regression & $1.081 \mathrm{E} 27$ & 3 & $3.603 \mathrm{E} 26$ & 234.527 & $.000^{\mathrm{a}}$ \\
& Residual & $9.218 \mathrm{E} 24$ & 6 & $1.536 \mathrm{E} 24$ & & \\
& Total & $1.090 \mathrm{E} 27$ & 9 & & & \\
\hline
\end{tabular}

a. Predictors: (Constant), Penduduk Bekerja, Belanja Daerah

b. Dependent Variable: PDRB

Tingkat Signifikan sebesar 0,00 dengan syarat jika tingkat signifikan lebih kecil dari 0,05, maka variabel tersebut berpengaruh signifikan.

Hasil perhitungan uji $\mathrm{F}$ (dalam tabel $\mathrm{ANOVA}^{\mathrm{b}}$ ) diperoleh nilai Sig $=0,000$. Berdasarkan perhitungan tersebut nilai Tingkat Sig lebih kecil $0,05(0,000<0,05)$, artinya dari pengujian secara bersama-sama yaitu variabel belanja daerah $\left(\mathrm{X}_{1}\right)$, tenaga kerja $\left(\mathrm{X}_{2}\right)$ memberikan pengaruh signifikan terhadap Produk Domestik Regional Bruto (PDRB) Provinsi Kalimantan Utara.

\section{Uji t}

Uji t untuk menguji koefisien $\mathrm{b}_{1}, \mathrm{~b}_{2}$, terhadap $\mathrm{Y}$ dengan tingkat kepercayaan (level of confident) 5 $\%$ dan tingkat kesalahan 5\% (0,05). Dapat dilihat pada tabel 5.2, hasilnya adalah sebagai berikut :

\section{a. Belanja Daerah $\left(\mathbf{X}_{1}\right)$}

Hasil perhitungan diperoleh nilai Sig $=0,010$ Jadi berdasarkan perhitungan tersebut nilai Tingkat Sig lebih kecil dari 0,05 $(0,010<0,05)$, artinya belanja daerah memberikan pengaruh signifikan terhadap Produk Domestik Regional Bruto (PDRB) Provinsi Kalimantan Utara. 


\section{b. Tenaga Kerja $\left(\mathbf{X}_{3}\right)$}

Hasil perhitungan diperoleh nilai $\mathrm{Sig}=0,000$ Jadi berdasarkan perhitungan tersebut nilai Tingkat Sig lebih kecil dari 0,000 $(0,000<0,05)$, artinya tenaga kerja memberikan pengaruh signifikan terhadap Produk Domestik Regional Bruto (PDRB) Provinsi Kalimantan Utara.

\section{A. Pembahasan \\ 1 Pengaruh Belanja Daerah terhadap Produk Domestik Regional Bruto}

Hasil penelitian ini menemukan adanya pengaruh yang signifikan antara variabel Belanja Daerah terhadap PDRB. Untuk menguji signifikansi masing-masing variabel secara individu dilakukan Uji tstatistik. Variabel Belanja Daerah i berpengaruh signifikan terhadap PDRB, karena tingkat $($ sig $<0,05)$ yaitu $(0,010<0,05)$. Belanja daerah berpengaruh langsung terhadap PDRB. Artinya semakin besar nilai belanja daerah yang dialokasikan untuk kegiatan pembangunan ekonomi maka diasumsikan nilai PDRB secara keseluruhan untuk wilayah Provinsi Kalimantan Utara meningkat.

Tentunya setiap daerah memiliki perbedaan hasil dalam peruntukan belanja pemerintah. Ada yang dipergunakan dengan benar akan tetapi ada yang dipergunakan hanya untuk kepentingan sesaat. Sebagai contoh : ketika pejabat pemerintah daerah akan mencalonkan diri sebagai Bupati atau Gubernur maka pejabat pemerintah daerah tersebut melakukan pembangunan daerah dengan baik, akan tetapi pembangunan tersebut dilakukan hanya ketika akan mencalonkan diri. Sehingga atas gambaran tersebut dapat peneliti simpulkan belanja pemerintah ada yang bernilai positif dan ada juga yang bernilai negatif.

Pengeluaran pemerintah mencerminkan kebijakan yang telah diambil oleh pemerintah. Apabila pemerintah telah menetapkan suatu kebijakan untuk membeli barang dan jasa, pengeluaran pemerintah mencerminkan biaya yang harus dikeluarkan untuk melaksanakan kebijakan tersebut. Pengeluaran pemerintah (government expenditure) semakin besar nilai yang dialokasikan maka semakin banyak kegiatan-kegiatan pembangunan yang dapat terlaksana. Contoh : pembangunan tempat bermain, infrastruktur. Apabila pembangunan ini terlaksana dengan baik maka diasumsikan pertumbuhan ekonomi juga akan meningkat atau tercapai targetnya. Pertumbuhan ekonomi yang tinggi diukur berdasarkan dari Produk Domestik Regional Bruto (PDRB). Secara teori hubungan belanja daerah terhadap PDRB dapat dibuat rumus $\mathrm{Y}=\mathrm{C}+\mathrm{I}+\mathrm{G}$. Artinya bila pengeluaran pemerintah bertambah maka pendapatan $(\mathrm{Y})$ akan meningkat (3)

\section{Pengaruh Tenaga Kerja terhadap Produk Domestik Regional Bruto}

Hasil penelitian ini menemukan adanya pengaruh yang signifikan antara variabel Tenaga Kerja terhadap PDRB, untuk menguji signifikansi masing-masing variabel secara individu dilakukan Uji tstatistik. Variabel Tenaga Kerjai berpengaruh signifikan terhadap PDRB, karena tingkat (sig < 0,05) yaitu $(0,000<0,05)$. Tenaga kerja berpengaruh langsung terhadap PDRB Artinya semakin besar tenaga kerja yang dipergunakan atau terserap maka nilai PDRB Provinsi Kalimantan Utara akan mengalami peningkatan.

Dalam penelitian ini diperoleh hasil bahwa tenaga kerja memberikan pengaruh signifikan terhadap PDRB Kalimantan Utara. Tenaga kerja adalah waktu yang dihabiskan untuk bekerja atau seluruh penduduk dalam usia kerja (berusia 15 tahun atau lebih) yang potensial dapat memproduksi barang dan jasa. Dalam rangka untuk memenuhi kebutuhan tenaga kerja dari perusahaan, maka pasar tenaga kerja ini dirasakan dapat memberikan jalan keluar bagi perusahaan untuk memenuhinya. Dengan demikian tidak terkesan hanya pencari kerja yang mendapat keuntungan dari adanya pasar ini. Agar tenaga kerja dapat bekerja dengan maksimal dan memperoleh hasil yang maksimal maka diperlukan kemampuan atau skill yang baik dan bagus. Sehingga dengan skill yang baik akan mudah dalam mengoperasikan teknologi yang tinggi dan mempercepat kinerja suatu perusahaan (4)

Tenaga kerja di Indonesia termasuk daerah Kalimantan Utara setiap tahunnya mengalami peningkatan. Artinya peningkatan adalah kebutuhan masyarakat untuk bekerja sangat tinggi. Sehingga apabila peningkatan ini tidak dibarengi dengan lapangan pekerjaan yang banyak maka akan menciptakan pengangguran. Investasi di Kaltim yang setiap tahunnya mengalami peningkatan dapat diartikan 
menciptakan lapangan pekerjaan yang tinggi. Sesuai teori produksi, $f(Q)$ dimana salah satunya tenaga kerja (labour) akan meningkatkan produksi. Produksi dalam penelitian ini menggambarkan tingkat PDRB Kalimantan Utara (5)

\section{Simpulan}

Kesimpulan sebagai berikut (1) Belanja Daerah secara langsung berpengaruh signifikan terhadap Produk Domestik Regional Bruto Provinsi Kalimantan Utara; (2) Tenaga Kerja secara langsung berpengaruh signifikan terhadap Produk Domestik Regional Bruto Provinsi Kalimantan Utara.

Saran yang dapat diberikan adalah pemerintah Provinsi Kalimantan Utara lebih memperhatikan pengeluaran atau belanja daerah yang diperuntukkan untuk kegiatan pembangunan dan diharapkan dapat menciptakan sumber-sumber pendapatan yang akan meningkatkan Pendapatan Asli Daerah, Pemerintah perlu memperhatikan Pendapatan Asli Daerah yang bersumber dari Pajak Daerah, Retribusi Daerah, Perusahaan Daerah dan Lain-lain Usaha daerah yang sah yang dianggap sebagai alternatif untuk memperoleh tambahan dana yang dapat digunakan untuk berbagai keperluan pengeluaran yang ditentukan oleh daerah sendiri .

\section{Bibliography}

1. Halim, Abdul. Bunga Rampai Manajemen Keuangan Daerah. Yogyakarta : UPP AMP YKPN, 2001. 2. Abdullah, Syukriy and Halim, Abdul. Wordpress.com. Wordpress.com. [Online] January 23, 2003. [Cited: 02 12, 2016.] http://syukriy.wordpress.com/2013/01/01/defisit-dan-surplus-dalamanggarandaerah-apakah-saling-berhubungan/.

3. Darise, Nurlan. Pengelolaan Keuangan Daerah. Jakarta : PT. Indeks, 2004.

4. Mangkoesoebroto, Guritno. Ekonomi Publik. Yogyakarta : PT. Intan Pariwara, 2003.

5. Diharwan. Analisis Pengaruh Investasi, Tenaga Kerja, dan Pengeluaran Pemerintah Terhadap Pertumbuhan Ekonomi Provinsi Sumatera Utara. Sumatera Utara : s.n., 2012. 